Marquette University

e-Publications@Marquette

1-1-1999

\title{
Relationships between Time Management, Control, Work-family Conflict, and Strain
}

Gary A. Adams

Marquette University, gary.adams@marquette.edu

Steve M. Jex

University of Wisconsin - Oshkosh

Accepted version. Journal of Occupational Health Psychology, Vol. 4, No. 1 (January 1999): 72-77. DOI. (C) 2019 American Psychological Association. Used with permission.

Gary Adams was affiliated with the University of Wisconsin - Oshkosh at the time of publication. 
Marquette University

e-Publications@Marquette

\title{
Management Faculty Research and Publications/College of Business
}

This paper is NOT THE PUBLISHED VERSION; but the author's final, peer-reviewed manuscript. The published version may be accessed by following the link in the citation below.

Occupational Health Psychology, Vol. 4, No. 1 (1999): 72-77. DOI. This article is (C) American Psychological Society and permission has been granted for this version to appear in ePublications@Marquette. American Psychological Society does not grant permission for this article to be further copied/distributed or hosted elsewhere without the express permission from American Psychological Society.

\section{Relationships Between Time Management, Control, Work-Family Conflict, and Strain}

\author{
Gary A. Adams \\ Department of Psychology, University of Wisconsin-Oshkosh \\ Department of Management, Marquette University
}

Steve M. Jex

Department of Psychology, University of Wisconsin-Oshkosh

\section{Abstract}

This article incorporates recent research regarding time management into a model of work-family conflict. The authors hypothesized that 3 types of time management behavior would have both direct and indirect (through perceived control of time) relationships, with work interfering with family and family interfering with work. It was also hypothesized that both of these types of work-family conflict would be related to the strain outcomes of job dissatisfaction and health complaints. This model was tested with a sample of 522 workers. In general, the hypothesized relationships were supported.

\section{Introduction}

Over the past 20 years, the demographic characteristics of the workforce have changed significantly. Prominent among these changes are the increased number of women, single parents, dual career, and dual earner couples 
who have chosen to participate in the workforce. These changes have brought with them the potential to affect the quality of work and family life (Higgins, Duxbury, \& Irving, 1992). They have also brought with them increased attention by researchers seeking to understand the conflict that can arise when participation in the work $(W)$ role interferes with participation in the family $(F)$ role $(W \rightarrow F)$ and vice versa $(F \rightarrow W)$. Much of this research has focused on identifying the antecedents and outcomes of this conflict (Burke, 1988; Frone, Russell, \& Cooper, 1992a).

The work-family conflict (WFC) literature suggests that work and family may interfere with each other in a number of ways (Greenhaus \& Parasuraman, 1987; Kanter, 1977; Voydanoff, 1988). One common form is timebased conflict, which occurs when time demands associated with participation in one role interfere with participation in the other role (Greenhaus \& Beutell, 1985). Research examining the antecedents of WFC has found that the amount of time devoted to work or family roles or both (Gutek, Searle, \& Klepa, 1991; O'Driscoll, Ilgen, \& Hildreth, 1992) and the scheduling of that time (Staines \& Pleck, 1984) are both related to WFC. Studies examining the outcomes of WFC have found higher levels of WFC are related to strains such as health complaints (Burke, 1988), job dissatisfaction (Bacharach, Bamberger, \& Conley, 1991; Wiley, 1987), and work and family distress (Frone et al., 1992a).

Although fewer in number, studies examining ways that WFC may be reduced have also begun to appear in the literature (e.g., Adams, King, \& King, 1996; Thomas \& Ganster, 1995). For instance, Thomas and Ganster (1995) have developed and tested a model linking family supportive workplace policies to WFC and strain outcomes. They found that family supportive programs such as flexible schedules and supportive supervisors were directly and indirectly (through perceived control) related to WFC. High levels of WFC were related to strains such as job dissatisfaction and health complaints. This research makes a convincing case for the importance of family supportive policies; however, in addition to such policies it seems likely that other factors such as personal characteristics may also serve to reduce WFC.

Because one of the primary forms of WFC is time-based conflict, one personal characteristic that seems particularly likely to reduce WFC is time management. That is, workers who are better able to manage their time may experience less WFC and its associated consequences than those who are less able to manage their time. Recent research investigating the effects of time management behavior has identified three clusters of these behaviors. They include (a) setting goals and priorities, (b) engaging in the mechanics of time management by making lists and schedules, and (c) having a preference for organization (Macan, 1994; Macan, Shahani, Dipboye, \& Phillips, 1990). This research also suggests that these time management behaviors help to reduce strains such as job dissatisfaction and somatic health complaints indirectly through their influence on perceived control of time (Macan, 1994). Recent time management research, however, has not examined the relationships between time management behaviors and WFC.

The purpose of the present study was to incorporate the findings by Macan (1994) regarding time management into the model of WFC proposed by Thomas and Ganster (1995). In the present study, we hypothesized that the three types of time management behavior would have both direct and indirect (through perceived control of time) relationships with WFC. We further hypothesized that WFC could be related to the strain outcomes of job satisfaction and health complaints (see Figure 1). 


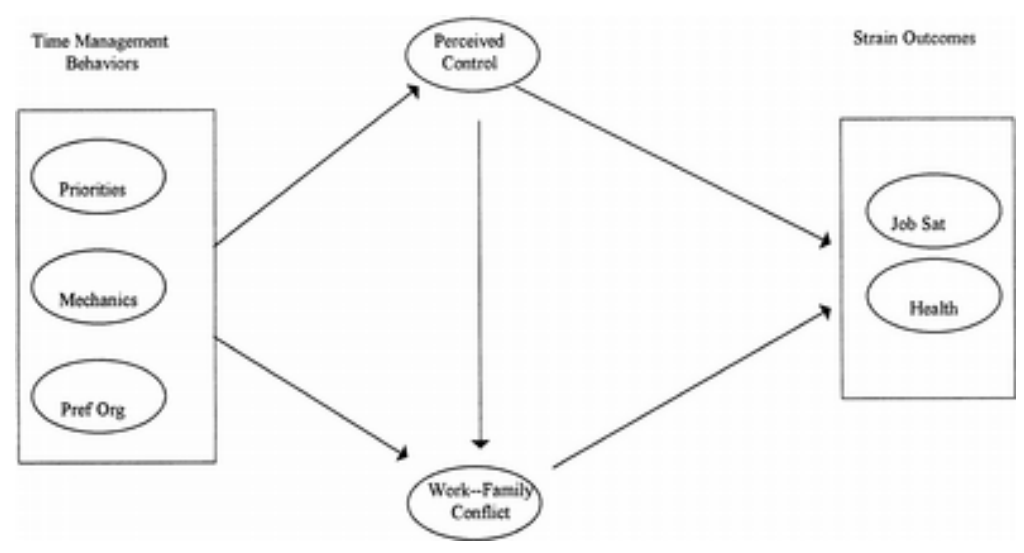

Figure 1. Hypothesized model relating time management behaviors, perceived control, and bidirectional workfamily conflict to strain outcomes. Priorities = setting goals and priorities; Mechanics = mechanics of time management; Pref Org = preference for organization; Perceived Control = perceived control of time; Job Sat = job satisfaction; Health = physical health

\section{Method}

A questionnaire was used to collect information on all variables. Time management behavior (33 items) and perceived control of time ( 5 items) were measured by using the scales developed by Macan et al. (1990). The three subscales of this measure (setting goals and priorities, engaging in the mechanics of time management, and having a preference for organization) have demonstrated acceptable levels of internal consistency (Macan et al., 1990). These self-reported ratings have also been shown to correlate highly with observations of time management behaviors made by supervisors, coworkers, and friends (Macan, 1994). The two types of workfamily conflict, W $\rightarrow$ F and $F \rightarrow W$, were each measured with two items from Frone, Russell, and Cooper's (1992b) bidirectional Work-Family Conflict Scale. Job satisfaction was measured with three items adapted from Hackman and Oldham's (1975) Job Diagnostic Survey. Health complaints were measured by using the 10-item version of Goldberg's (1978) General Health Questionnaire. All variables were scored such that a higher score reflected higher standing on the construct measured.

\section{Analysis}

First, we calculated summary statistics for all variables (see Table 1). We then computed a separate path analysis by using ordinary least squares regression for each type of WFC and each strain to examine the relationships presented in Figure 1.

Table 1. Means, Standard Deviations, Correlations, and Reliability Estimates for All Variables $(N=490)$

\begin{tabular}{|c|c|c|c|c|c|c|c|c|c|c|c|c|c|}
\hline Variable & M & SD & 1 & 2 & 3 & 4 & 5 & 6 & 7 & 8 & 9 & 10 & 11 \\
\hline Age (years) & 36.02 & 8.63 & -- & & & & & & & & & & \\
\hline $\operatorname{Sex}^{\mathrm{a}}$ & 1.66 & 0.48 & -05 & -- & & & & & & & & & \\
\hline Marital status ${ }^{b}$ & 1.37 & 0.48 & -25 & .18 & -- & & & & & & & & \\
\hline Priorities & 3.71 & 0.72 & .08 & .09 & -03 & .90 & & & & & & & \\
\hline Mechanics & 3.47 & 0.86 & .10 & .16 & -03 & .61 & .88 & & & & & & \\
\hline Preference for organization & 3.92 & 0.73 & -03 & .13 & .04 & .34 & .33 & .68 & & & & & \\
\hline Perceived control & 3.02 & 0.67 & .03 & -03 & .01 & .17 & .07 & .30 & .57 & & & & \\
\hline Work interfering with family & 3.23 & 1.03 & .05 & .02 & -10 & .02 & .02 & -23 & -.28 & .44 & & & \\
\hline
\end{tabular}




\begin{tabular}{|l|l|l|l|l|l|l|l|l|l|l|l|l|l|}
\hline Family interfering with work & 2.09 & 0.92 & -.04 & -.02 & -.05 & -.10 & -.09 & -.11 & -.22 & .11 & .84 & & \\
\hline Job satisfaction & 3.76 & 0.95 & .16 & -.02 & -.12 & .17 & .20 & .08 & .30 & -.14 & -.18 & .88 & \\
\hline Health & 2.47 & 0.53 & -.15 & .18 & .07 & -.24 & -.17 & -.23 & -.43 & .31 & .18 & -.53 & .88 \\
\hline
\end{tabular}

Note. Elements in main diagonal are alphas. Correlations greater than .10 are significant at $p<.05$; correlations greater than 12 are significant at $p<.01$.

${ }^{\text {a }}$ Coded 1 = female, 2 = male.

${ }^{\mathrm{b}}$ Coded 1 = married, 2 = not married

\section{Results and Discussion}

The results of the path analyses are presented in Figures 2,3,4 and 5. As can be seen in the figures, many of the hypothesized relationships were supported. In general, the time management behaviors influenced health and job satisfaction indirectly through perceived control and WFC. The results also support the notion that workers who perceive themselves as having greater control over their time experience lower $F \rightarrow W(\beta=-.19)$ and $W \rightarrow$ $F(\beta=-.22)$. However, there were important differences depending on the type of time management behavior, the type of WFC, and the type of strain outcome examined.

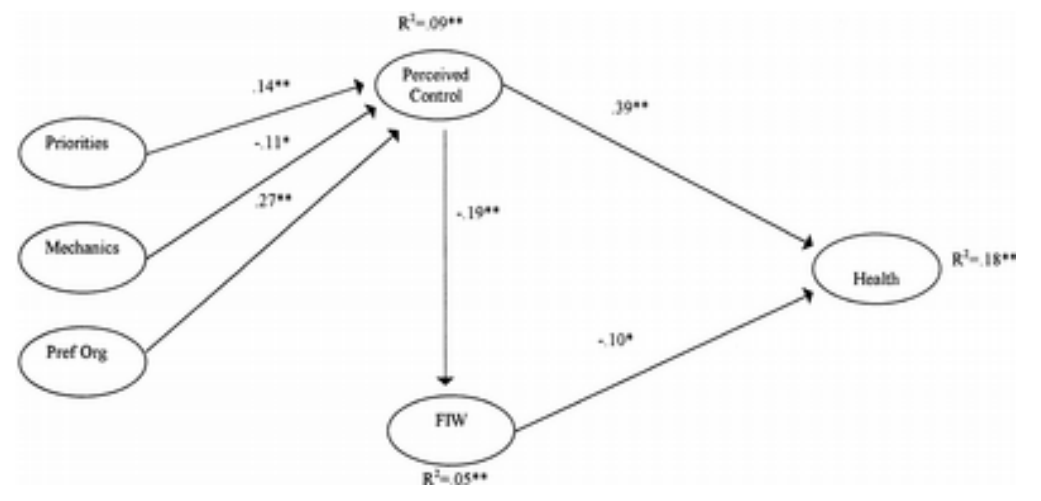

Figure 2. Path model of relationships among time management behaviors, perceived control, family interfering with work, and health. Only analyzed paths significant at $* p<.05$ are included. Priorities = setting goals and priorities; Mechanics = mechanics of time management; Pref Org = preference for organization; Perceived Control $=$ perceived control of time; Health = physical health; FIW = family interfering with work. ${ }^{* *} p<.01$

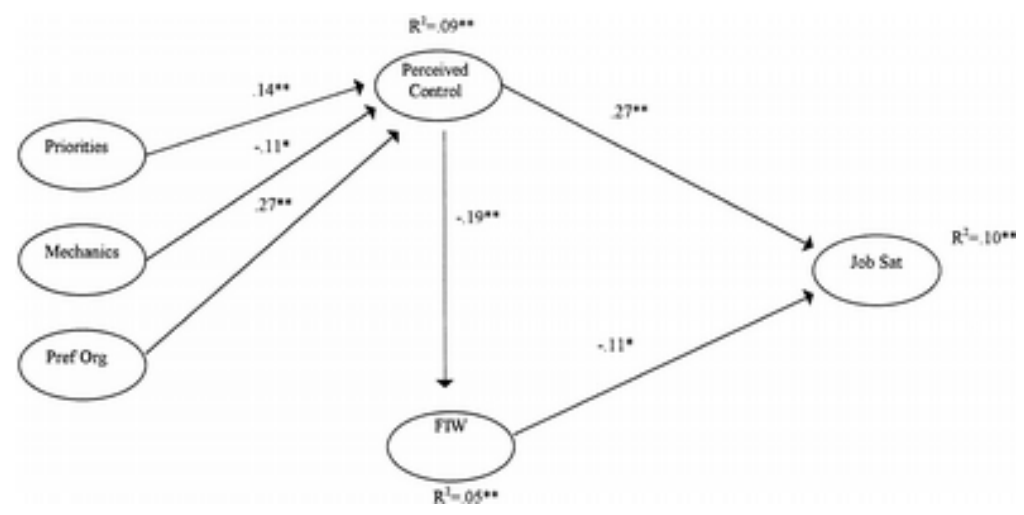

Figure 3. Path model of relationships among time management behaviors, perceived control, family interfering with work, and job satisfaction. Only analyzed paths significant at $* p<.05$ are included. Priorities $=$ setting goals and priorities; Mechanics = mechanics of time management; Pref Org = preference for organization; Perceived Control $=$ perceived control of time; Job Sat $=$ job satisfaction; FIW $=$ family interfering with work. ${ }^{* *} p<.01$ 


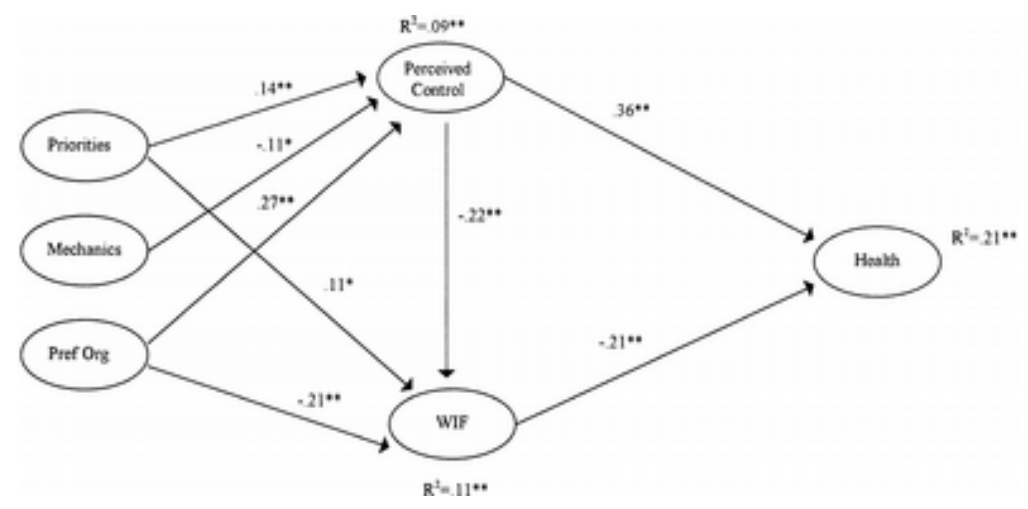

Figure 4. Path model of relationships among time management behaviors, perceived control, work interfering with family, and health. Only analyzed paths significant at ${ }^{*} p<.05$ are included. Priorities $=$ setting goals and priorities; Mechanics = mechanics of time management; Pref Org = preference for organization; Perceived Control $=$ perceived control of time; Health $=$ physical health; WIF $=$ work interfering with family. ${ }^{* *} p<.01$

Each of the three types of time management behavior were related to perceived control. It is interesting to note that these relationships were not all in the same direction. Setting priorities and having a preference for organization were positively related to perceived control ( $\beta=.14$ and .27 , respectively), whereas engaging in the mechanics of time management had a negative relationship with perceived control $(\beta=-.11)$. Thus it would appear that making lists and schedules may actually lead some people to experience less control over their time than if they did not engage in these behaviors. This is consistent with Macan's (1994) suggestion that keeping lists and schedules may provide people with feedback regarding their time management efforts. For those who are not meeting all of their time demands, uncompleted tasks on a list and missed appointments on a schedule may lead them to perceive they have little control over their time.

The relationships between the time management behaviors and WFC differed depending on which type of WFC was examined. For instance, some of the time management behaviors had direct and indirect relationships (through perceived control) with $\mathrm{W} \rightarrow \mathrm{F}$, whereas their influence was wholly indirect when $\mathrm{F} \rightarrow \mathrm{W}$ was examined. This finding suggests possible differences between the antecedents of the two types of WFC and further highlights the need to examine them separately.

One unexpected finding was in regard to the sign of the path coefficient relating goal setting-prioritization to $\mathrm{W}$ $\rightarrow F$. The sign of this path was positive, suggesting that setting goals and priorities may lead to higher levels of W $\rightarrow$ F. Given that some research has suggested that workers may allow work to interfere with family more often than the reverse (Frone et al., 1992b), one explanation for this is that work-related activities are given a higher priority than family-related activities. Unfortunately, we were unable to test this explanation in this study, but it does pose an interesting question for future research.

In examining the relationships between perceived control and WFC and the outcomes, perceived control was significantly related to both health and job satisfaction regardless of the type of WFC. Regarding WFC, F $\rightarrow$ W was related to both health $(\beta=-.10)$ and job satisfaction $(\beta=-.11)$, as hypothesized. $W \rightarrow F$ was related to health $(\beta=-.21)$, as hypothesized, but not to job satisfaction. Taken together, these findings suggest that those with lower levels of control and higher levels of WFC experience higher levels of distress. The finding that W $\rightarrow \mathrm{F}$ was not related to job satisfaction is consistent with some past research that suggests those who are highly involved with and committed to their work may experience higher job satisfaction while at the same time experiencing greater WFC (Adams et al., 1996; Sekaran, 1989; Wiley, 1987).

Overall, the results of this study endorse the model relating family supportive organizational practices to control, WFC, and outcomes advocated by Thomas and Ganster (1995) and extend it by incorporating Macan's 
(1994) time management model. In general, the results support the notion that time management, as a family supportive practice undertaken by an individual, operates in much the same manner as family supportive practices enacted by organizations. Thus it appears that strain outcomes arising out of WFC could be reduced through the efforts of both the individual worker and the employer. Further, those efforts that increase control perceptions may be particularly beneficial. For instance, organizations might accomplish this through the use of flexible work schedule arrangements whereas individuals might accomplish this through the use of time management techniques or by learning to use more active coping strategies.

\section{References}

Adams, G. A., King, L. A., \& King, D. W. (1996). Relationships of job and family involvement, family social support, and work-family conflict with job and life satisfactionJournal of Applied Psychology, 81, 411-420.

Bacharach, S. B., Bamberger, P., \& Conley, S. (1991). Work-home conflict among nurses and engineers: Mediating the impact of role stress on burnout and satisfaction at workJournal of Organizational Behavior, 12, 39-53.

Burke, R. J. (1988). Some antecedents and consequences of work-family conflictJournal of Social Behavior and Personality, 3, 287-302.

Frone, M. R., Russell, M., \& Cooper, M. L. (1992a). Antecedents and outcomes of work-family conflict: Testing a model of the work-family interfaceJournal of Applied Psychology, 77, 65-78.

Frone, M. R., Russell, M., \& Cooper, M. L. (1992b). Prevalence of work-family conflict: Are work and family boundaries asymmetrically permeable?Journal of Organizational Behavior, 13, 723-729.

Goldberg, D. (1978). Manual of the general health questionnaire. London: Oxford University Press.

Greenhaus, J. H., \& Beutell, N. J. (1985). Sources of conflict between work and family rolesAcademy of Management Review, 10, 76-88.

Greenhaus, J. H., \& Parasuraman, S. (1987). A work-nonwork interactive perspective of stress and its consequences. In J. M.Ivancevich \& D. C.Ganster (Eds.), Job stress: From theory to suggestion (pp. 3760). New York: Haworth.

Gutek, B. A., Searle, S., \& Klepa, L. (1991). Rational versus gender role explanations for work-family conflictJournal of Applied Psychology, 76, 560-568.

Hackman, J. R., \& Oldham, G. R. (1975). Development of the Job Diagnostic SurveyJournal of Applied Psychology, $60,159-170$.

Higgins, C. A., Duxbury, L. A., \& Irving, R. H. (1992). Work-family conflict in the dual career familyOrganizational Behavior and Human Decision Processes, 51, 51-75.

Kanter, R. M. (1977). Work and family in the United States: A critical review of agenda for research and policy. New York: Russell Sage Foundation.

Macan, T. (1994). Time management: Test of a process modelJournal of Applied Psychology, 79, 381-391.

Macan, T., Shahani, C., Dipboye, R. L., \& Phillips, A. P. (1990). College students' time management: Correlations with academic performance and stressJournal of Educational Psychology, 82, 760-768.

O'Driscoll, M. P., Ilgen, D. R., \& Hildreth, K. (1992). Time devoted to job and off-job activities, interrole conflict, and affective experiencesJournal of Applied Psychology, 77, 272-279.

Sekaran, U. (1989). Paths to the job satisfaction of bank employeesJournal of Organizational Behavior, 10, 347359.

Staines, G. L., \& Pleck, J. H. (1984). Nonstandard work schedules and family lifeJournal of Applied Psychology, 69, 515-523.

Thomas, L. T., \& Ganster, D. C. (1995). Impact of family supportive work variables on work-family conflict and strain: A control perspectiveJournal of Applied Psychology, 80, 6-15.

Voydanoff, P. (1988). Work and family: A review and expanded conceptualizationJournal of Social Behavior and Personality, 3, 1-22.

Wiley, D. L. (1987). The relationship between work/nonwork role conflict and job-related outcomes: Some unanticipated findingsJournal of Management, 13, 467-472. 